\title{
Determination of Nurses' Attitudes and Beliefs on Sexual Care Towards Urology Patients
}

\author{
Hemșirelerin Üroloji Hastalarına Yönelik Cinsel Bakıma İlișkin Tutum ve İnançlarının \\ Belirlenmesi
}

\author{
Aliye Okgün Alcan', Serpil Çetin', Ezgi Seyhan Ak², Yeliz Çulha², Ayfer Özbaș² \\ 1 Izmir Bakircay University, Faculty of Health Science, Nursing Department, Izmir, Turkey \\ 2 Istanbul University, Cerrahpasa Florence Nightingale Faculty of Nursing, Istanbul, Turkey
}

Geliș tarihi (Submitted): 2020-09-09 Kabul tarihi (Accepted): 2021-01-05

Yazışma / Correspondence
Aliye Okgun Alcan
Gazi Mustafa Kemal Mah, Kaynaklar
Cad. Seyrek, Menemen
35665, Izmir / Turkey
Email: aliye.alcan@bakircay.edu.tr,
aliyeokgun@gmail.com
Phone:+90 23249300 00/11242
Fax: +90 2328447122
ORCID
A.O.A $\quad 0000-0002-6889-363 X$
S.Ç. $\quad 0000-0003-0922-7060$
E.S.A. $\quad 0000-0002-3679-539 X$
$\begin{aligned} & \text { Y.Ç. } \quad 0000-0002-5460-5844 \\ & \text { A.Ö. } \quad 0000-0003-0924-5752\end{aligned}$

This work is licensed under a Creative Commons Attribution-NonCommercial 4.0 International License.

\section{Özet}

Amaç: Tanımlayıcı tipteki bu araştırmanın amacı üroloji hemşirelerinin cinsel bakıma ilişkin tutum ve inançlarının belirlenmesidir.

Gereç ve Yöntemler: Bu çalışmanın verileri Mayıs-Ağustos 2020 tarihleri arasında internet üzerinden toplanmıştır. Çalışmanın örneklemini, çalışmaya katılmayı gönüllü olarak kabul eden, internet kullanabilen, üroloji hastalarına bakım verilen kliniklerde çalışan 118 hemşire oluşturmuştur. Araştırmanın verileri hemşirelerin sosyodemografik özelliklerine yönelik sorular ve Cinsel Tutum ve İnanç Ölçeği'ni içeren veri toplama formu kullanılarak toplanmıștır. Verilerin analizinde sayı ve yüzde dağılımı, Kruskal-Wallis, MannWhitney U testi, Spearman Korelasyon Analizi kullanılmıştır.

Bulgular: Hemşirelerin yaş ortalaması 32,61 $\pm 6,73$ (min:22, maks:46) yaş olarak belirlenmiştir. Bu çalışmada Cinsel Tutum ve İnançlar Ölçeği ortalama puanı 40,86 $\pm 8,57$ (min:15 maks:65) olarak belirlenmiştir. Hemşirelerin \%79,7'sinin (n:94) hastalarının cinsel sorunlarını tartışmak için zaman ayırmadığı saptanmıştır. Hemşirelerin medeni durumu (U:1190,00 p:0,010) ve cinsel bakım konusunda eğitim alma (U:1052,00 p:0,007) durumlarının cinsel tutum ve inançlarını etkilediği saptanmıştır. Hemşirelerin hastalarına cinsel bakıma ilişkin danışmanlık verme konusunda kendilerini yeterli hissetme puan ortalamalarının 10 üzerinden 4,25 $\pm 2,39$ (min:0 maks:10) olduğu belirlenmiştir. Hemşirelerin hastalarına cinsel ba-

\section{Abstract}

Objective: The aim of this descriptive research is to determine the attitudes and beliefs of urology nurses regarding sexual care.

Material and Methods: The data of this study were collected via internet between May and August 2020. The sample of the study consisted of 118 nurses who voluntarily agreed to participate in the study, able to use internet and working in clinics which urology patients are cared for. The data of the study were collected using data collection form that consists questions regarding the sociodemographic characteristics of the nurses and Sexual Attitudes and Belief Scale. Number and percentage distribution, Kruskal-Wallis, MannWhitney U test, Spearman Correlation Analysis were used in the analysis of the data.

Results: It was determined that the average age of the nurses was $32.61 \pm 6.73$ (min:22, max:46) years. In this study, the mean score of the Sexual Attitudes and Beliefs Scale was determined as $40.86 \pm 8.57$ (min:15 max:65). It was found that $79.7 \%$ (n:94) of the nurses did not spare time to discuss the sexual problems of their patients. It was found that the marital status of the nurses (U:190.00 p:0.010) and being educated about sexual care (U:1052.00 p:0.007) affected their sexual attitudes and beliefs. It was determined that the mean score of the nurses to feel themselves competent in providing counseling regarding sexual care to their patients was $4.25 \pm 2.39$ (min:0, max:10) out of 10 . It was determined that the

The study was approved by the Ethics Committee of Izmir Bakircay University (Approval number: 2020/08-08) and the Board of Directors of the Association of Urology Nurses. All research was performed in accordance with relevant guidelines/regulations, and informed consent was obtained from all participants. 
kıma ilişkin danışmanlık verirken kendilerini rahat hissetme puan ortalamalarının ise 10 üzerinden 4,32 $\pm 2,63$ (min:0 maks:10) olduğu saptanmıştır.

Sonuç: Bu çalışma sonucunda üroloji hemşirelerinin hastalara cinsel bakıma yönelik danışmanlık vermesinde orta düzeyde engel olduğu, kendilerini yeterli ve rahat hissetmedikleri belirlenmiştir. Hemşirelik eğitim müfredatlarının cinsel sağlık ve bakım konusunda güçlendirilmesi önerilmektedir.

Anahtar Kelimeler: Üroloji; cinsel bakım; tutum; inanç mean score of the nurses for feeling comfortable while giving counseling to their patients regarding sexual care was $4.32 \pm 2.63$ out of 10 (min:0 to max:10).

Conclusion: In conclusion, it has been determined that urology nurses have a moderate obstacle in providing consultancy to patients about sexual care, and do not feel comfortable and comfortable. It is recommended to strengthen nursing education curricula on sexual health and care.

Keywords: Urology; nurse; sexual care; attitude; belief

\section{INTRODUCTION}

Sexuality and healthy sexual life are important and inseparable parts of being human as they are considered to be significant indicators of life quality $(1,2)$ practice, attitude and beliefs toward sexual health assessment of patients with coronary artery diseases in practice. Descriptive correlational design was used; the sample consisted of 84 nurses in cardiac clinics at two major educational hospitals. Data collection included demographic data and nurses' knowledge and practice of sexual health assessment. Nurses' attitude was measured using Sexuality Attitude and Belief Survey (SABS). There are many factors that affect individuals' sexual lives. One of the most important factors is the diseases that especially affect the systemic structure and functions of the urinary system and surgical treatment methods. Urinary system diseases and treatments may cause certain symptoms and complications that affect life quality negatively by making changes in genital hormones, organs, and structures(3). Sexual dysfunction is one of the most important complications of the disease and the treatment process. Along with sexual dysfunction, these patients also experience problems with sexual desire and mental health, sexual function disorder due to the different ejaculation and orgasm process, and different dynamics of the couple's intimacy(3). However, if the patient has a stoma, the change in the physical appearance may cause changes in sexual life. When the sexual lives of individuals are affected due to any diseases or treatments, their physical, social, and mental healths are also affected. This leads to a decrease in the life qualities of individuals $(2,4,5)$ epidemiologic data on sexual dysfunction are relatively scant for both women and men. Objective To assess the prevalence and risk of experiencing sexual dysfunction across various social groups and examine the determinants and health consequences of these disorders. Design Analysis of data from the National Health and Social Life Survey, a probability sample study of sexual behavior in a demographically representative, 1992 cohort of US adults. Participants A national probability sample of 1749 women and 1410 men aged 18 to 59 years at the time of the survey. Main Outcome Measures Risk of experiencing sexual dysfunction as well as negative concomitant outcomes. Results Sexual dysfunction is more prevalent for women (43\%).

According to the American Nursing Association (1974), 'evaluation of the individuals' sexual healths and revealing their sexual concerns' are parts of professional nursing applications(6). According to The North American Nursing Diagnosis Association (Nanda, 1980), 'Sexual Function Disorder' is among nursing diagnosis(7). This shows that sexual problems should be addressed by nurses around the world.

Urology nurses also have significant responsibilities for giving counseling on sexual care. The responsibilities of urology nurses for sexual care are the evaluation of sexual health, determination of the problem, solving the problem by applying proper nursing initiatives, and maintaining sexual health $(8,9)$. Studies on sexuality show that patients are willing to tell their sexual problems to nurses; however, nurses cannot be efficient in sexual care both because their knowledge about sexuality is not adequate and their beliefs about sexual care. (10-14)beliefs, and practices regarding sexuality care for patients with cardiovascular disease. Background: Limited sexual activity is common among patients with cardiovascular disease, yet assessment of sexuality 
and counselling is frequently not undertaken by nurses. Design: Cross-sectional study. Methods: This study recruited 268 cardiac nurses from seven tertiary hospitals in five cities of Henan province. The Sexual Attitudes and Beliefs Survey, along with investigator-developed questions regarding practices and perceived barriers, was administered to the nurses. The STROBE checklist was used to ensure quality reporting during this observational study (see Supporting Information Data S1 Nurses do not consider sexual care as their responsibility, which leads to insufficient time for sexual problems. However, nurses are health professionals that individuals meet the first and for the longest time in healthcare organizations, and they have a key role in giving sexual care. Also, it is important that factors which affect the nurses' attitudes and beliefs about the evaluation of sexuality and counseling to increase the life quality of the patients. For this reason, the present study was conducted to identify the attitudes and beliefs of urology nurses regarding sexual care.

\section{MATERIAL AND METHODS}

The data of the present study (descriptive type) were collected by using an online survey system between the dates May-August 2020. The sample of the study was 118 service and polyclinic nurses who worked in clinics that provided care for urology patients during study time, who could use the internet, and who agreed to participate in the study. Surgical and intensive care nurses were not included in the study.

The data of the study were collected by the researchers through the internet data collection form which was created in accordance with the related literature. The data collection form consisted of two sections. The first section consisted of 24 questions that aimed to evaluate the nurses' socio-demographic information and their experiences in sexual care. Socio-demographic characteristics included age, gender, marital status, educational status, the hospital, working time in the profession, and urology clinic where they worked. Experiences in sexual care evaluated their information resources about sexual care and sexual counseling experiences for the patients that they provided care for. The second section of the form included the sexual attitude and belief scale (SABS). The scale was used to determine nurses' attitudes and beliefs about sexual care. The sexual attitude and belief scale was developed by Reynolds and Magnan in 2005. Cronbach's Alpha value of the original scale was 0.75 and 0.82 in repetitive measurements. Adaptation of the scale to Turkish was made by Ayhan et al. Cronbach's alpha value of the Turkish scale was 0.73 . The scale consisted of 12 items. Marking was performed on a 6-point Likert-type scale for each item. To avoid biasness when answering the scale, 6 of the 12 items (1., 2., 4., 6., 8., 10., 12. items) scored in reverse. The lowest score that could be taken from the scale was 12 , the highest score was 72 . A high scale score indicated an increase in negative attitudes and beliefs about sexual care(12).

The data collection form was published electronically on May 26, 2020, at http://www.surveey.com/ SurveyStart.aspx?lang $=1 \&$ surv $=6 \mathrm{c} 8 \mathrm{c} 55 \mathrm{f} 1 \mathrm{f} 2054 \mathrm{e} 7 \mathrm{~b}$ 92496fc6d90e9637. An invitation that consisted of the objective and link of the study was sent to nursing groups on social media and nurses registered in the Urology Nurses Association via e-mail. To increase participation, a reminder message was sent to nurses two weeks after the first invitation letter was sent. IP auditing was provided to ensure that the participant completed the survey only once. It took the nurses about 7-10 minutes to complete the data collection form. Data collection forms that were filled out online were backed up daily by researchers.

The study was approved by the Ethics Committee of Izmir Bakircay University (Approval number: 2020/0808) and the Board of Directors of the Association of Urology Nurses. The necessary explanations about the objective and application of the study were given to the nurses who participated in the study in the first part of the data collection form. Filling out the question form in accordance with this information was accepted as an approval for participation in the study. Written permission was obtained by e-mail for the sexual attitude and belief scale to be used in the research.

The data that were obtained from the study were analyzed in the Statistical Package for the Social Sciences (SPSS) 20.0 program. Number and percentage distributions were used to evaluate the data. The Shapiro Wilk test was used to determine whether the data 
showed normal distribution. Kruskal-Wallis, Mann Whitney U test, Spearman Correlation Analysis were used for nonparametric data. In all results, values that were less than p-value 0.05 were considered statistically significant $(\mathrm{p}<0.05)$.

\section{RESULTS}

Of the nurses who participated in the study, $89.8 \%$ (n: 106) were women, $61.0 \%$ (n: 72) were married. The average age of nurses was $32.61 \pm 6.73$ (min: 22, max: 46) years old. Of the nurses, $5.1 \%$ (n: 6) graduated from the vocational school of health, 5.1\% (n: 6) had associate degrees, $62.7 \%$ (n: 74) had bachelor's degrees, and $27.1 \%$ (n: 32) had master degrees. The study found that of the nurses, $11.9 \%$ (n: 14) worked in private hospitals, $40.7 \%$ (n: 48 ) worked in a hospital affiliated to the Ministry of Health, and $47.5 \%$ (n: 45) worked in university hospitals. The median working time of nurses in the profession was 9 (min: 1, max: 25) years, and the median working time as a urology nurse was 2 (min: 1, max: 20 ) years. It was found that $47.5 \%$ (n: 56 ) of the nurses who participated in the study provided care only for urology patients in the clinics where they worked.

Table 1 shows the distribution of the sexual care experiences of the nurses who participated in the study. Of the nurses, $78.0 \%$ (n: 92) stated that providing care and counseling about sexual subjects was one of the responsibilities of nurses. The average score of nurses' feeling adequate in giving sexual counseling to patients was $4.25 \pm 2.39$ (min: 0 max: 10) over 10 . The average score of nurses' feeling comfortable when giving sexual counseling to patients was $4.32 \pm 2.63$ (min: 0 max: 10 ) over 10.

Table 2 shows the distribution of factors affecting nurses' giving counseling to their patients on sexual concerns/care.

Table 3 shows the nurses' average scores of sexual attitude and belief scale. The study found that SABS item score averages varied between 2.59 and 4.34, and scale total score average was $40.86 \pm 8.57$ (min: 15 max: 65).

The study found that there was no statistically significant difference between the nurses' ages, sexes, the hospitals where they worked, their working time at the profession as urology nurses, and the patient group for which they provided care and the SABS total score average $(\mathrm{p}>0.05)$.

It was determined that the average SABS score of married nurses was significantly higher than the average SABS score of single nurses (U: 1190.00 p: 0.010).

The study found that the SABS score averages of nurses who did not receive training on sexual care were significantly higher than those who received training (U: 1052.00 p: 0.007).

The study found that SABS score averages of nurses who did not believe that it was one of the nurses' responsibilities to provide care and counseling on sexual subjects were higher than those who believed it was nurses' responsibility (U: 530.00 p: 0.0001).

The study found that there was a negatively significant correlation between the SABS score averages and nurses' feeling adequate (r: -0.318 p: 0.0001) and comfortable ( $\mathrm{r}$ : -0.464 p: 0.0001) in giving counseling on sexual care.

\section{DISCUSSION}

The present study, in which the Sexual Attitude and Belief Scale score average was 40.86 \pm 8.57 (min:15 max:65), found that there was a mediocre obstacle to the nurses to evaluate the patients' sexual problems and give counseling accordingly. The SABS score averages in the studies that were conducted in Turkey varied between 41.58 and 44.65(10,15-18). When compared to the similar studies that were conducted in Turkey, the lowest score average was determined in the present study. Thus, it can be said that the nurses who participated in the present study had fewer obstacles to the evaluation of sexual problems and giving counseling accordingly. It is believed that this difference is since the sample group consisted of urology nurses who may be more experienced as they encounter a group of patients with more needs for sexual care when compared to other nurses' group.

The results of the present study were found to be similar to the study that was conducted by Saunamäki et al. (2010) in Sweden(5). Also, it was found that the results of the present study were lower than the results of the studies that were conducted in countries where eastern culture is dominant, such as China and Jordan $(1,2,11)$. The results were found to be higher 
Table 1. Distribution of nurses' experience of sexual care

\begin{tabular}{|c|c|c|}
\hline & $\mathbf{n}$ & $\%$ \\
\hline \multicolumn{3}{|c|}{ Status of receiving training for sexual care } \\
\hline Received & 38 & 32.2 \\
\hline Did Not Receive & 80 & 67.8 \\
\hline \multicolumn{3}{|c|}{ Willingness to receive training in sexual care and counseling } \\
\hline Willing & 90 & 76.3 \\
\hline Not Willing & 28 & 23.7 \\
\hline \multicolumn{3}{|c|}{ Status of giving counseling to patients on sexual care } \\
\hline Provides & 44 & 37.3 \\
\hline Does Not Provide & 74 & 62.7 \\
\hline \multicolumn{3}{|c|}{ Status of the existence of a protocol regarding sexual care in the institution } \\
\hline Exists & 2 & 1.7 \\
\hline Does Not Exist & 80 & 67.8 \\
\hline Does Not Know & 36 & 30.5 \\
\hline \multicolumn{3}{|c|}{ Frequency of conversation with patients about sexual concerns/care } \\
\hline Never & 42 & 35.6 \\
\hline Rarely & 58 & 49.2 \\
\hline Sometimes & 14 & 11.9 \\
\hline Often & 2 & 1.7 \\
\hline Always & 2 & 1.7 \\
\hline \multicolumn{3}{|c|}{ Frequency of actively initiating conversation with patients about sexual concerns/care } \\
\hline Never & 48 & 40.7 \\
\hline Rarely & 40 & 33.9 \\
\hline Sometimes & 22 & 18.6 \\
\hline Often & 6 & 5.1 \\
\hline Always & 2 & 1.7 \\
\hline
\end{tabular}

Table 2. Distribution of factors that affect nurses to give counseling to their patients on sexual concerns/care

\begin{tabular}{|lcc|}
\hline Affecting Factors & n & \% \\
\hline Fearing that sexual activity will affect the patient's health & 34 & 28.8 \\
The Patient's Being Single & 38 & 32.2 \\
The age gap between nurses and patients & 38 & 32.8 \\
Not considering sexual concerns as problems & 44 & 37.3 \\
Patients' being old & 54 & 45.8 \\
Shyness & 64 & 54.2 \\
Feeling uncomfortable & 68 & 57.6 \\
Believing that sexual issues are too private to discuss with patients & 70 & 59.3 \\
Lack of time & 72 & 61.0 \\
Lack of information & 78 & 66.1 \\
Uncertainty of how to communicate with patients & 80 & 67.8 \\
Lack of experience & 80 & 67.8 \\
Believing that patients would not want to talk about their sexual concerns with nurses & 84 & 86 \\
Lack of safe and private environments & 88.4 \\
Fearing that patients might be offended/embarrass & 72.9 & 74.6 \\
\hline
\end{tabular}


Table 3. Sexual attitude and belief scale score averages of nurses

\begin{tabular}{|c|c|c|c|c|c|}
\hline \multirow[t]{2}{*}{ Scale Items } & \multirow{2}{*}{$\overline{\mathrm{x}} \pm \mathrm{SS}$} & \multicolumn{2}{|c|}{ Participated } & \multicolumn{2}{|c|}{ Did Not Participate } \\
\hline & & $\mathrm{n}$ & $\%$ & $\mathrm{n}$ & $\%$ \\
\hline $\begin{array}{l}{ }^{*} \text { Discussion of sexuality is necessary for the health of the } \\
\text { patient. }\end{array}$ & $2.64 \pm 1.51$ & 86 & 72.9 & 32 & 27.1 \\
\hline $\begin{array}{l}\text { * I understand how my patients' diseases and treatments } \\
\text { can affect their sexuality. }\end{array}$ & $3.02 \pm 1.26$ & 70 & 59.3 & 48 & 40.7 \\
\hline $\begin{array}{l}\text { I am uncomfortable talking about issues related to } \\
\text { sexuality. }\end{array}$ & $2.93 \pm 1.39$ & 88 & 74.6 & 30 & 25.4 \\
\hline $\begin{array}{l}{ }^{\star} \text { I am more comfortable talking to my patients about } \\
\text { sexual issues than most nurses I work with. }\end{array}$ & $3.64 \pm 1.51$ & 50 & 42.4 & 68 & 57.6 \\
\hline $\begin{array}{l}\text { I believe most hospitalized patients are too sick to deal } \\
\text { with sexuality. }\end{array}$ & $2.95 \pm 1.52$ & 80 & 67.8 & 38 & 32.2 \\
\hline $\begin{array}{l}\text { * I create time for my patients to discuss their sexual } \\
\text { problems. }\end{array}$ & $4.34 \pm 1.32$ & 24 & 20.3 & 94 & 79.7 \\
\hline $\begin{array}{l}\text { When my patients ask me questions about sexuality, I } \\
\text { suggest they talk to their doctor about it. }\end{array}$ & $3.61 \pm 1.55$ & 64 & 54.2 & 54 & 45.8 \\
\hline $\begin{array}{l}\text { * I trust my ability to diagnose the patient's sexual } \\
\text { problems. }\end{array}$ & $3.97 \pm 1.47$ & 40 & 33.9 & 78 & 66.1 \\
\hline Sexuality is a too private to discuss with patients. & $3.32 \pm 1.55$ & 70 & 59.3 & 48 & 40.7 \\
\hline $\begin{array}{l}\text { * It is a nursing responsibility to allow the patient to talk } \\
\text { about their sexual problems. }\end{array}$ & $3.63 \pm 1.62$ & 50 & 42.4 & 68 & 57.6 \\
\hline $\begin{array}{l}\text { Sexuality should only be discussed if it is initiated by the } \\
\text { patient. }\end{array}$ & $2.59 \pm 1.21$ & 98 & 83.1 & 20 & 16.9 \\
\hline $\begin{array}{l}\text { * Patients expect nurses to ask questions about their } \\
\text { sexual problems. }\end{array}$ & $4.22 \pm 1.33$ & 26 & 22.0 & 92 & 78.0 \\
\hline Total Score & $40.86 \pm 8.57$ & & & & \\
\hline
\end{tabular}

${ }^{*}$ Positive expressions

than the results of the studies that were conducted in countries where western culture is dominant, such as America and Portugal $(13,19)$. It is believed that this was because the attitudes and beliefs about sexual care show differences across cultures. It can be said that giving counseling on sexual care is an obstacle to nurses as a cultural taboo in eastern cultures.

In the literature, it is stated that the obstacles that the nurses face while giving counseling on sexual care show differences $(10,16-20)$. The present study found that the average score of "I create time to discuss my patients' sexual problems" item was the highest $(4,34 \pm 1,32)$. Also, it was found that the majority of the nurses $(79.7 \%)$ did not take the time to discuss their patients' sexual problems. Similarly, it is stated that the biggest obstacle to nurses is to create time for their patients' sexual problems in the literature $(5,16-18,21)$.
This attitude is believed to be due to the fact that nurses do not consider sexual care as a priority alongside workload.

The study found that the SABS score averages of nurses who did not receive training on sexual care were significantly higher than those who received training (U: 1052.00 p: 0.007). In other words, it was determined that nurses who received training on sexual care faced fewer obstacles when giving counseling to their patients on sexual care. This is an expectable result. It is known that as healthcare professionals become more knowledgeable about sexual care, their perceived obstacles to sexual care decrease $(5,17,20,22)$. In this context, the results are similar to the literature.

A study by Gültürk et al. (2018) found that single nurses face fewer obstacles when giving counseling on sexual care than married nurses(18). The present study 
also found that single nurses felt fewer obstacles when giving counseling on sexual care.

As a result, it was determined that the rates of urology nurses in giving counseling to patients on sexual care were limited. In addition, it was found that nurses had a moderate obstacle to giving counseling on sexual care, and they did not feel adequate and comfortable. In this direction, it is recommended that undergraduate, graduate, and in-service education programs include more issues related to sexual health and care.

\section{Conflict of interest}

All authors declare no conflict of interest.

\section{Funding}

No funding received for this work.

\section{Ethical Approval}

The study was approved by the Ethics Committee of Izmir Bakircay University (Approval number: 2020/08-08) and the Board of Directors of the Association of Urology Nurses and written informed consent was received from all participants. The study protocol conformed to the ethical guidelines of the Helsinki Declaration.

\section{REFERENCES}

1. Bdair IA, Maribbay GL. Perceived knowledge, practices, attitudes and beliefs of jordanian nurses toward sexual health assessment of patients with coronary artery diseases. Sex Disabil 2020;38:491-502.

2. Zeng YC, Li Q, Wang N, Ching SSY, Loke AY. Chinese nurses' attitudes and beliefs toward sexuality care in cancer patients. Cancer Nurs 2011;34(2):0-6.

3. Chung E, Brock G. Sexual rehabilitation and cancer survivorship: a state of art review of current literature and management strategies in male sexual dysfunction among prostate cancer survivors. J Sex Med 2013;10 Suppl(1):102-11.

4. Laumann EO, Paik A, Rosen RC. Sexual dysfunction in the United States: Prevalence and predictors. J Am Med Assoc 1999;281(6):537-44.

5. Saunamäki N, Andersson M, Engström M. Discussing sexuality with patients: Nurses' attitudes and beliefs. J Adv Nurs 2010;66(6):1308-16.
6. Alligood M. Nursing Theorist and Their Work. 8th Edition. USA: Mosby, 2013: 99-110.

7. Büyükkayacı D, Vural G. Cinsel sağlığın değerlendirilmesi. In: Büyükkayacı Duman N (Editör). Cinsel Sağlık. Nobel Tip Kitabevleri, 2019: 47-58.

8. Appoloni Eduardo AH, Napoleão AA, Carvalho EC de. Nursing interventions for patients with erectile dysfunction after radical prostatectomy : integrative review. Enfermería Glob 2016;42:456-72.

9. Gomes C, Eduardo A, Mosteiro-Diaz M, Pérez-Paniagua J, Napoleão A. Nursing interventions for urinary incontinence and sexual dysfunction after radical prostatectomy. Acta Paul Enferm 2019;32(1):106-12.

10. Demirgöz Bal M. Hemşirelerin cinsel bakıma ilişkin tutum ve inançları. Hemşirelikte Eğitim ve Araştırma Dergisi 2014;11(3):38-42.

11. Wang P, Ai J, Davidson PM, Slater T, Du R, Chen C. Nurses' attitudes, beliefs and practices on sexuality for cardiovascular care: A cross-sectional study. J Clin Nurs 2019;28(56):980-6.

12. Ayhan $\mathrm{H}$, Iyigun $\mathrm{E}$, Tastan $\mathrm{S}$, Coskun $\mathrm{H}$. Turkish version of the reliability and validity study of the sexual attitudes and belief survey. Sex Disabil 2010;28(4):287-96.

13. Reynolds K, Magnan M. Nursing Attitudes and Beliefs Toward Human Sexuality: Collaborative Research Promoting Evidence-Based Practice. Clin Nurse Spec 2005;19(5):255-9.

14. Gölbaşı Z, Evcili F. Hasta cinselliğinin değerlendirilmesi ve hemşirelik: engeller ve öneriler. Anadolu Hemşirelik ve Sağlık Bilim Dergisi 2013;16(3):182-9.

15. Piran $M$, Yücel Ç. Perinatal alanda çalışan hemşire ve ebelerin bakımda cinselliği ele alma konusunda yaşadığ engeller ve kolaylaştırıcı faktörlerin belirlenmesi. Yüksek Lisans Tezi, Ankara:Hacettepe Üniversitesi Sağlık Bilimleri Enstitüsü, 2019.

16. Arikan F, Meydanlioglu A, Ozcan K, Canli Ozer Z. Attitudes and beliefs of nurses regarding discussion of sexual concerns of patients during hospitalization. Sex Disabil 2015;33(3):327-37.

17. Gök F, Demir Korkmaz F. Sexual counseling provided by cardiovascular nurses: Attitudes, beliefs, perceived barriers, and proposed solutions. J Cardiovasc Nurs 2018;33(6):E24-30.

18. Gültürk E, Akpınar A, Şen ŞR, Balc1 H. Cinselliğin değerlendirilmesi: Hemşirelerin cinsellikle ilgili tutum ve inançları. FNG Bilim Tıp Dergisi 2018;4(1):63-70. 
19. da Silva Dias H, Santana Fialho Sim-Sim M. Validation of the sexuality attitudes and beliefs survey (SABS) for the Portuguese population. Acta Paul Enferm 2015;3:196-201.

20. Magnan M, Reynolds K, Galvin E. Barriers to addressing patient sexuality in nursing practice. Medsurg Nurs 2005;5:282-9.
21. Algier L, Sultan KAV. Nurses' approach to sexuality-related issues in patients receiving cancer treatments. Turkish J Cancer 2008;38(3):135-41.

22. Russell EB. Sexual Health Attitudes, Knowledge, and Clinical Behaviors: Implications for Counseling. Fam J 2012;20(1):94-101. 